\title{
The mineralogical characterization of argentian cryptomelane from Xiangguang Mn-Ag deposit, North China
}

\author{
Chenzi FAN ${ }^{*}$, Ling WANG ${ }^{* *}$, Xingtao FAN ${ }^{*}$, Yu ZHANG ${ }^{* * *}$ and Linghao ZHAO ${ }^{*}$ \\ *National Research Center for Geoanalysis, Beijing, 100037, P.R. China \\ ${ }^{* *}$ College of Mining Engineering, North China University of Science and Technology, Tangshan, 063009, P.R. China \\ ${ }^{* * *}$ Faculty of Materials Science and Chemistry, China University of Geosciences, Wuhan, 430074, P.R. China
}

\begin{abstract}
Argentian cryptomelane as a quite rare variety is determined during the investigation of $\mathrm{Mn}-\mathrm{Ag}$ ore samples from Xiangguang deposit along the northern margin of North China craton. The mineral observed by a polarizing petrographic microscope involves concentric ring-band, pisolitic and veinlet structures and greyish white color. The scanning electron microscopy reveals a large number of elongated nanocrystals in the forms of nanofibers and nanorods in this densely natural argentian cryptomelane. The specifically chemical features in two samples of $\mathrm{XG}-\mathrm{C}-1$ and $\mathrm{XG}-\mathrm{C}-2$ of cryptomelane are:

(1) $\left(\mathrm{K}_{0.55} \mathrm{Na}_{0.08} \mathrm{Ca}_{0.06} \mathrm{Zn}_{0.04} \mathrm{Ag}_{0.03} \mathrm{~Pb}_{0.02} \mathrm{Mg}_{0.01}\right)_{0.79}\left(\mathrm{Mn}_{7.21} \mathrm{Fe}_{0.52} \mathrm{Al}_{0.09} \mathrm{Si}_{0.09}\right)_{7.91} \mathrm{O}_{16} \bullet n \mathrm{H}_{2} \mathrm{O}$;

(2) $\left(\mathrm{K}_{0.37} \mathrm{Ca}_{0.28} \mathrm{Ag}_{0.13} \mathrm{Na}_{0.07} \mathrm{Mg}_{0.07} \mathrm{Zn}_{0.06} \mathrm{Cu}_{0.02}\right)_{1.00}\left(\mathrm{Mn}_{7.01} \mathrm{Fe}_{0.40} \mathrm{Al}_{0.39} \mathrm{Si}_{0.03} \mathrm{Ti}_{0.01} \mathrm{Cr}_{0.01}\right){ }_{7.85} \mathrm{O}_{16} \bullet n \mathrm{H}_{2} \mathrm{O}$.

The silver content ranges from about $0.22-3.15 \mathrm{wt} \%$, which is much higher than that of other manganese oxides including ranciéite, chalcophanite and coronodite found in this deposit as well. Both of two argentian cryptomelane samples feature two main Raman scattering contributions at about $580 \mathrm{~cm}^{-1}$ and $630 \mathrm{~cm}^{-1}$, belonging to the $\mathrm{Mn}-\mathrm{O}$ lattice vibrations within the $\mathrm{MnO}_{6}$ octahedral double chains, which can distinguish from other three manganese oxides. The $\mathrm{Ag}^{+}$prefers to locate in the tunnel sites substituting $\mathrm{K}^{+}$of cryptomelane due to its large radius and the same monovalent state with $\mathrm{K}^{+}$. Some chain-width disorders characterized by transmission electron microscopy are probably caused by these cation substitutions.
\end{abstract}

Keywords: Cryptomelane, Silver, Mineralogical characterization, Xiangguang deposit, Raman spectroscopy

\section{INTRODUCTION}

Manganese oxide minerals are ubiquitous in a wide variety of geological setting, but silver-bearing manganese oxides are considered as quite rare mineral phases. Radtke et al (1967) first described 'Aurorite' [(Mn,Ag, Ca) $\mathrm{Mn}_{3} \mathrm{O}_{7} \bullet 3 \mathrm{H}_{2} \mathrm{O}$ ] with chalcophanite structure as a new mineral at the Aurora mine, the $\mathrm{Ag}$ content of which can reach $7.5 \mathrm{wt} \%\left(\mathrm{Ag}_{2} \mathrm{O}\right)$. An argentian todorokite (3.9 wt\% $\mathrm{Ag}_{2} \mathrm{O}$ ) and unnamed silver bearing lead manganese oxide $\left(1.2 \mathrm{wt} \% \mathrm{Ag}_{2} \mathrm{O}\right)$ were also reported in these black calcite veins. At the San Miguel Tenango mine Ag was described by Gómez-Caballero et al (2010) to occur as nanometric particles of native silver adsorbed on the external surfaces of todorokite and of the amorphous phase.

All these kinds of silver-bearing manganese oxides

doi:10.2465/jmps. 150119

C. Fan, czfan2013@163.com Corresponding author are mainly found in $\mathrm{Mn}-\mathrm{Ag}$ type deposits. So far over fifteen kinds of manganese oxides have been identified in the worldwide $\mathrm{Mn}-\mathrm{Ag}$ deposits, but the content results indicate only a few kinds such as cryptomelane, coronadite, todorokite and chalcophanite carry most of the silver (Radtke et al., 1967; Hildebrand and Mosier, 1974; Li et al., 1996). The complex occurrences and distributions of $\mathrm{Ag}$ associated with fine-grained $\mathrm{Mn}$ oxide minerals also contribute to the problems of low recovery in the metallurgical process despite high Ag grades (GómezCaballero et al., 2010; Tian et al., 2012).

Cryptomelane $\left(\mathrm{K}_{\mathrm{x}} \mathrm{Mn}_{8-\mathrm{x}} \mathrm{O}_{16}\right.$, where $\left.0.2 \leq \mathrm{x} \leq 1\right)$, essentially potassium manganese oxide, is the most abundant mineral of supergene manganiferous ore (Post, 1999). Argentian cryptomelane as a new variety was only reported to be found containing a few ppm to $1 \mathrm{wt} \% \mathrm{Ag}$ in the Silver Cliff mining district of Colorado (Anderson et al., 1973). A silver content of $1 \mathrm{wt} \%$ produces no observable structural change at this mine (Hildebrand and 
Mosier, 1974). The natural samples from Colorado exhibit very similar coordination distances as the synthetic cryptomelane which silver ions were sorbed onto (Ravikumar et al., 1998). Recently manganese oxides with the cryptomelane structure modified with silver have been demonstrated as Ag-hollandite $\left(\mathrm{Ag}_{\mathrm{x}} \mathrm{Mn}_{8} \mathrm{O}_{16}\right.$, where $1 \leq$ $\mathrm{x} \leq 1.8$ ) by many material scientists. The $\mathrm{Ag}^{+}$center in a tunnel consisting of double chains of edge-sharing $\mathrm{MnO}_{6}$ octahedra has the potential to be electrochemically and catalytically active (Takeuchi et al., 2012, 2013; Özacar et al., 2013). The presence of silver causes partial replacement of potassium from the channels and distortion of the cryptomelane structure (Gac, 2006). The cube-like cavities are created by face-sharing cubes of $\mathrm{O}^{2-}$ atoms with $\mathrm{Ag}$ atoms occupying the shared faces of the $\mathrm{O}^{2-}$ cubes. The occupancy of the Ag atoms at the shared faces of the cube-like cavities yields a peculiar square planar $\mathrm{Ag}^{+}$environment with bond distances of approximately $2.7 \AA$, which are a little larger than $\mathrm{Ag}^{+}-\mathrm{O}^{2-}(2.35 \AA)$ (Takeuchi et al., 2012).

In this communication we characterize argentian cryptomelane in $\mathrm{Mn}-\mathrm{Ag}$ ores from the Xiangguang deposit, North China. The silver content is evaluated from $0.22-3.15 \mathrm{wt} \%$ in cryptomelane which is much higher than that in other manganese minerals of ranciéite, chalcophanite and coronadite found in the deposit. The aim of the present work is to provide a framework for better understanding distribution of $\mathrm{Ag}$ and possible substitution mechanisms for $\mathrm{Ag}$ incorporation. It may give more information on the metallurgical process and the origin of mineralization.

\section{OCCURENCE}

Specimens were collected from Xiangguang deposit, Hebei Province, which is typically related to volcanic and subvolcanic epithermal deposits along the northern margin of North China craton (Fig. 1). The area is located in the southwest of Xiaofanshan syncline in Yanshan fold belt and southeast of Xiangguang Mesozoic volcanic rift basin. $\mathrm{Mn}-\mathrm{Ag}$ mineralization is strictly controlled by NNW-striking and NE-dipping compression-shear structural zone. The orebodies occur and develop largely at the site of the structural fracture zone especially at the cross section of unconformity between Zhangjiakou and Houcheng Formations. The igneous rocks in this area include extrusive rocks of rhyolitic ignimbrite and intrusive rocks of granite porphyry. Quartzitification - clayization - limonitization and propylitization are the two main types of the wall rock alteration, and the former type is highly close to $\mathrm{Mn}-\mathrm{Ag}$ mineralization. The $\mathrm{Mn}-\mathrm{Ag}$ orebodies are mainly hosted within tuffaceous greywacke in Zhangjiakou For- mation and rhyolitic ignimbrite and granite porphyry in Houcheng Formation of Jurassic (Liu et al., 2012). The collected ores are classified into two types: a Mn-Ag ore and an alteration ore, in both of which the mineral assemblages are essentially the same but the relative contents have some variation.

\section{EXPERIMENTAL}

The epoxy-impregnated thin-sections of ore specimens were examined with both reflected and transmitted light with a Leica optimal microscope. The magnified details of selected zones were subsequently observed with Quanta 650 FEG and FEI Nano scanning electron microscope (SEM) with energy-dispersive spectrometry (EDS) and back-scattered electron (BSE) imaging capabilities. The quantitative mineral chemistry was analyzed using a JXA-8230 Electron probe by wavelength-dispersive spectrometry (EMPA). Operating conditions were an accelerating voltage of $15 \mathrm{kV}$, a beam current of $20 \mathrm{nA}$ and a beam diameter about 2-5 $\mu \mathrm{m}$. The analysis of Ag content was carried out on the Finnigan Element II double focusing magnetic sectorfield ICP-MS equipped with a high-performance New Wave $193 \mathrm{~nm}$ ArF excimer laser-ablation system in spot ablation with size of $40 \mu \mathrm{m}$ (LA-ICP-MS). Calibration was performed using the silicate glass standards of NIST610 and KL2G. The raw analytical data were corrected for instrument drift and converted to concentration values using known values of manganese as an internal standard by the formula:

$$
C_{u}^{s a m}=\frac{k_{u} C_{i}^{s a m} I_{u}^{s a m}}{I_{i}^{s a m}} .
$$

In this formula $k=$ relative sensitivity factor of element analyzed; $C=$ concerntration; sam $=$ unknown sample; $I=$ counts per second; $u=$ element analyzed; $i=$ internal standard element. The mineral identification was carried out with powder X-ray diffraction (XRD) using a RIGAKU-RA diffractometer with $\mathrm{Cu} \mathrm{X}$-ray source. The Raman spectrums of manganese oxides between $100 \mathrm{~cm}^{-1}$ and $3600 \mathrm{~cm}^{-1}$ were recorded using a Horiba Jobin-Yvon LabRAM HR800 system with a wavelength of $632 \mathrm{~nm}$ and spot sizes of 2-3 $\mu \mathrm{m}$. A JEOL JEM-2010 microscope was used for high resolution transmission microscopy (HRTEM) and operated at $120 \mathrm{keV}$ to examine cryptomelane crystal structure. Small amounts of manganese oxides for analysis were removed from specimens by micro-drilling tools. A drop of the resulting suspension in ethanol was placed on a holey carbon film supported by a TEM Cu grid. 


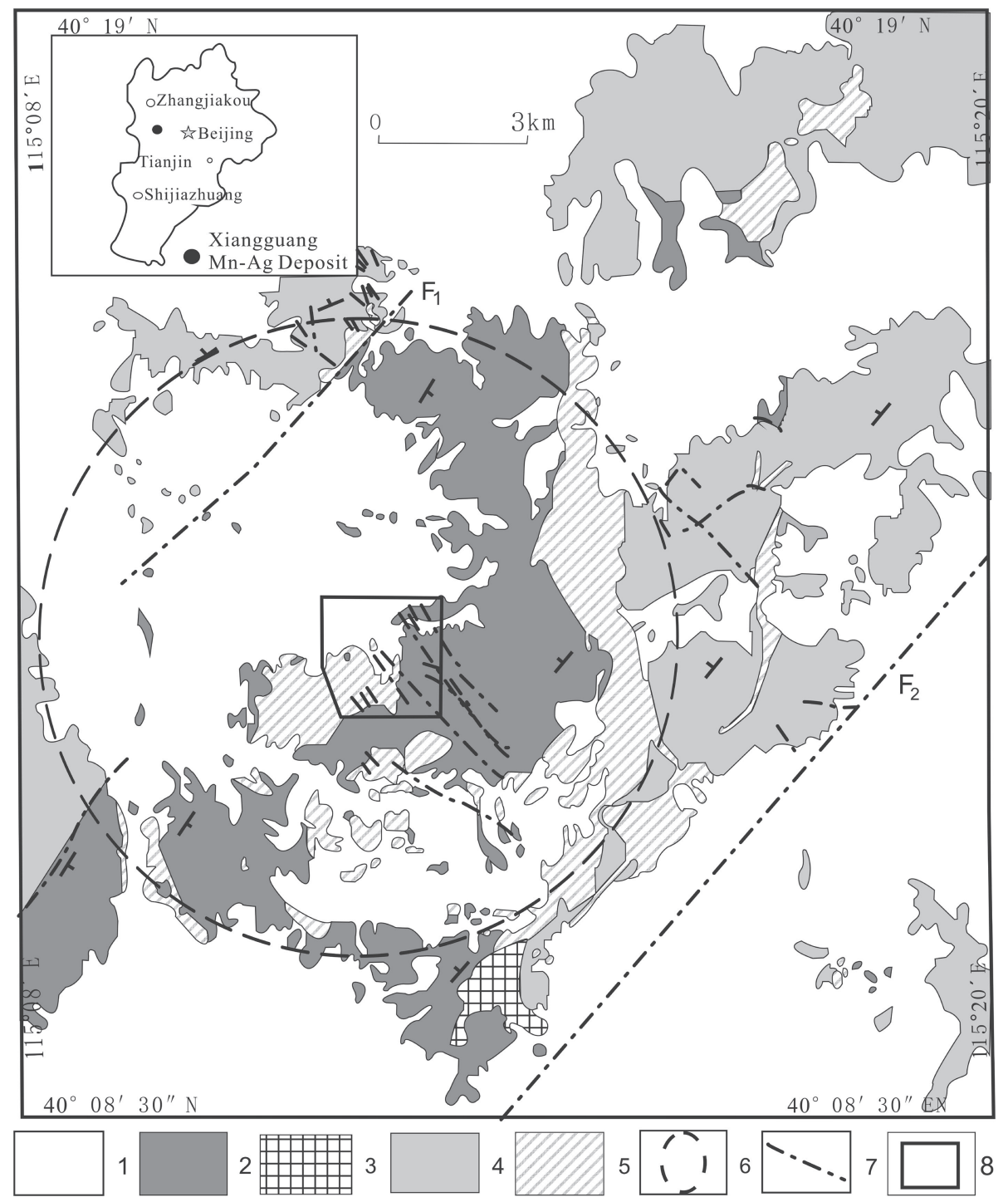

Figure 1. Simplified geological map of Xiangguang Mn-Ag deposit (referenced from Liu et al., 2012). 1, sediment (Quaternary); 2, sandstone, conglomerate, dolomitic breccia in Houcheng Formation and rhyolitic ignimbrite, siltstone, conglomerate in Zhangjiakou Formation (Jurassic); 3, limestones intercalated with shales (Cambrian); 4, dolomite intercalated with shales and banded chert (Proterozoic); 5, granite porphyry, quartz porphyry, syenite porphyry breccia and diorite (Jurassic); 6, tectonic boundary of paleo volcanos; 7 , fault; 8 , the boundary of the deposit.

\section{RESULTS}

\section{Appearance}

The physical characteristics of silver-bearing cryptomelane are recognized as dull black on the surface, steelgray to bluish-gray color on fresh fracture, brownishblack for streak, hardness of 6-7. Under a microscope it occurs as veins (Fig. 2a), nodules (Fig. 2b), colloform banding and concentric rings (Fig. 2c) with greyish white to light brown reflected color. SEM images show the grain dimensions and features of cryptomelane go into the nano-range. The crystals extend along one direction with various morphologies of rice-shaped rods (Fig. 2d) to wavy, fibrous forms (Fig. 2e) in the sample entitled $\mathrm{XG}-\mathrm{C}-1$, or align into two-dimensional plate or sheet configuration in the sample entitled $\mathrm{XG}^{-} \mathrm{C}-2$ (Fig. 2f).

\section{Chemical compositions}

Two groups of EMPA data in Table 1 exhibit the difference of cryptomelane compositions. The contents of $\mathrm{K}_{2} \mathrm{O}$ in $\mathrm{XG}-\mathrm{C}-1$ are $3.23-4.03 \mathrm{wt} \%$ which are close to reported 3.05-3.35 wt $\%$ in the natural cryptomelane from Xiangtan manganese deposit in China (Lu et al., 2003). However, the $\mathrm{K}_{2} \mathrm{O}$ contents are lower (1.90-2.90 wt\%) but $\mathrm{CaO}$ contents (1.01-2.44 wt\%) are higher in $\mathrm{XG}-\mathrm{C}-$ 2 than those in $\mathrm{XG}-\mathrm{C}-1$. Since the EMPA cannot distinguish $\mathrm{Mn}^{2+}, \mathrm{Mn}^{3+}$ from $\mathrm{Mn}^{4+}$, we contribute total $\mathrm{Mn}$ to $\mathrm{MnO}_{2}$ form due to only minor $\mathrm{Mn}^{2+}, \mathrm{Mn}^{3+}$ in cryptomelane. The general empirical formula for the argentian cryptomelane calculated on the basis of $\mathrm{O}=16$ can be written as

XG-C-1: $\quad\left(\mathrm{K}_{0.55} \mathrm{Na}_{0.08} \mathrm{Ca}_{0.06} \mathrm{Zn}_{0.04} \mathrm{Ag}_{0.03} \mathrm{~Pb}_{0.02} \mathrm{Mg}_{0.01}\right)_{0.79}$ $\left(\mathrm{Mn}_{7.21} \mathrm{Fe}_{0.52} \mathrm{Al}_{0.09} \mathrm{Si}_{0.09}\right)_{7.91} \mathrm{O}_{16} \bullet n \mathrm{H}_{2} \mathrm{O}$ 


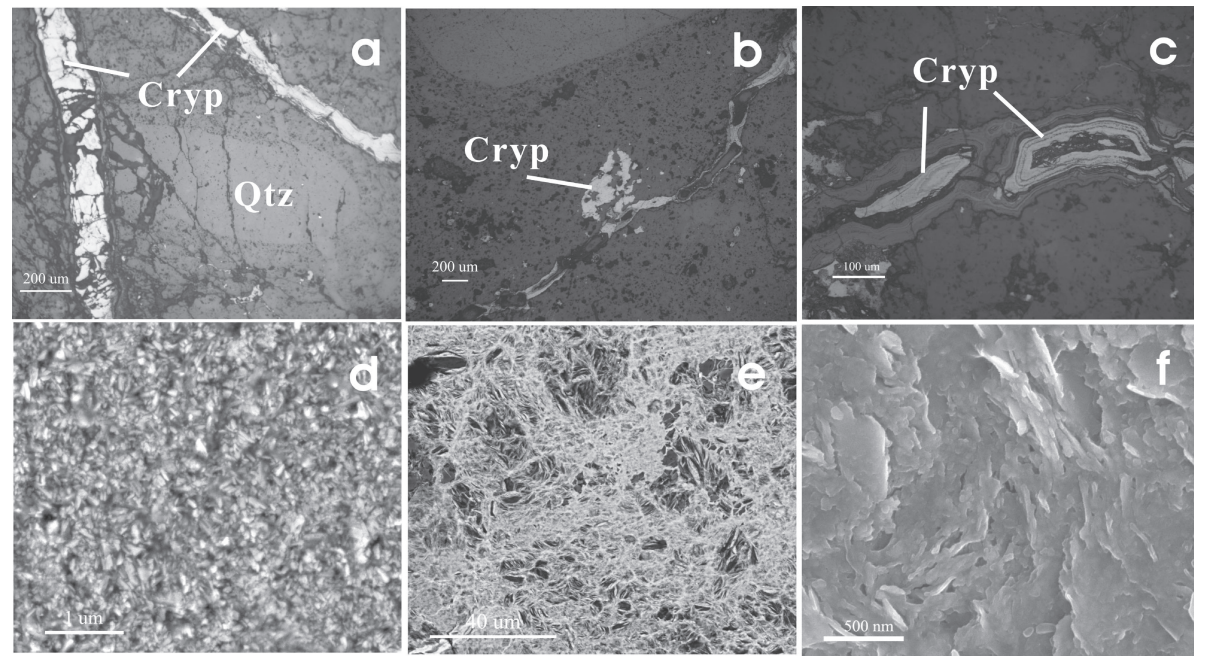

Figure 2. Reflected-light (a), (b), (c) and SEM (d), (e), (f) photomicrographs of argentian cryptomelane from Xiangguang deposit. (a) veinlet structure; (b) nodular structure; (c) colloform banding; (d) riceshaped rod habit; (e) fibrous habit; (f) nanorod and plate habit.

Table 1. Electron microprobe analyzer (EMPA) data (wt\%) of cryptomelane

\begin{tabular}{|c|c|c|c|c|c|c|c|c|c|c|c|c|c|c|c|c|c|}
\hline XG-C-1 & $\mathrm{a}_{2} \mathrm{O}$ & $\mathrm{MgO}$ & $\mathrm{l}_{2} \mathrm{O}_{3}$ & $\mathrm{SiO}_{2}$ & $\mathrm{~K}_{2} \mathrm{O}$ & $\mathrm{CaO}$ & $\mathrm{PbO}$ & $\mathrm{Fe}_{2} \mathrm{O}_{3}$ & $\mathrm{TiO}_{2}$ & $\mathrm{ZnO}$ & $\mathrm{BaO}$ & $\mathrm{Ag}_{2} \mathrm{O}$ & $\mathrm{CuO}$ & $\mathrm{NiO}$ & $\mathrm{MnO}_{2}$ & $\mathrm{Cr}_{2} \mathrm{O}_{3}$ & Total \\
\hline 1 & 0.46 & 0.02 & 0.35 & 0.73 & 3.40 & 0.33 & 0.62 & 4.62 & 0.03 & 0.39 & 0.00 & 0.39 & 0.00 & 0.01 & 87.09 & 0.05 & 98.49 \\
\hline 2 & 0.34 & 0.06 & 0.43 & 0.26 & 3.51 & 0.36 & 0.49 & 5.22 & 0.00 & 0.35 & 0.10 & 0.43 & 0.00 & 0.00 & 87.34 & 0.04 & 98.92 \\
\hline 3 & 0.29 & 0.04 & 0.69 & 0.36 & 3.39 & 0.52 & 0.84 & 6.54 & 0.00 & 0.36 & 0.36 & 0.50 & 0.00 & 0.00 & 83.77 & 0.01 & 97.65 \\
\hline 4 & 0.20 & 0.08 & 1.23 & 1.92 & 3.23 & 0.59 & 1.13 & 7.97 & 0.05 & 0.46 & 0.16 & 0.34 & 0.00 & 0.00 & 78.99 & 0.14 & 96.48 \\
\hline 5 & 0.34 & 0.04 & 0.43 & 0.40 & 3.56 & 0.45 & 0.37 & 6.37 & 0.07 & 0.34 & 0.00 & 0.44 & 0.08 & 0.00 & 85.48 & 0.00 & 98.38 \\
\hline 6 & 0.67 & 0.07 & 0.28 & 0.14 & 4.03 & 0.20 & 0.10 & 2.28 & 0.00 & 0.56 & 0.00 & 0.34 & 0.00 & 0.00 & 92.39 & 0.00 & 101.07 \\
\hline 7 & 0.21 & 0.09 & 1.37 & 2.11 & 3.74 & 0.46 & 0.17 & 5.53 & 0.00 & 0.31 & 0.03 & 0.48 & 0.01 & 0.01 & 85.93 & 0.04 & 100.49 \\
\hline 8 & 0.27 & 0.05 & 0.47 & 0.23 & 3.47 & 0.56 & 0.43 & 6.72 & 0.00 & 0.59 & 0.13 & 0.43 & 0.00 & 0.12 & 85.19 & 0.12 & 98.79 \\
\hline Average & 0.35 & 0.06 & 0.65 & 0.77 & 3.54 & 0.44 & 0.52 & 5.66 & 0.02 & 0.42 & 0.10 & 0.42 & 0.01 & 0.02 & 85.77 & 0.05 & 98.78 \\
\hline XG-C-2 & $\mathrm{Na}_{2} \mathrm{O}$ & $\mathrm{MgO}$ & $\mathrm{Al}_{2} \mathrm{O}_{3}$ & $\mathrm{SiO}_{2}$ & $\mathrm{~K}_{2} \mathrm{O}$ & $\mathrm{CaO}$ & $\mathrm{PbO}$ & $\mathrm{Fe}_{2} \mathrm{O}_{3}$ & $\mathrm{TiO}_{2}$ & $\mathrm{ZnO}$ & $\mathrm{BaO}$ & $\mathrm{Ag}_{2} \mathrm{O}$ & $\mathrm{CuO}$ & $\mathrm{NiO}$ & $\mathrm{MnO}_{2}$ & $\mathrm{Cr}_{2} \mathrm{O}_{3}$ & Total \\
\hline 1 & 0.35 & 0.43 & 2.64 & 0.25 & 2.42 & 2.26 & 0.00 & 4.32 & 0.19 & 0.58 & 0.07 & 1.87 & 0.26 & 0.06 & 80.70 & 0.18 & 96.56 \\
\hline 2 & 0.33 & 0.43 & 2.63 & 0.26 & 1.90 & 2.44 & 0.00 & 5.56 & 0.00 & 0.73 & 0.00 & 1.59 & 0.18 & 0.00 & 77.90 & 0.22 & 94.16 \\
\hline 3 & 0.38 & 0.38 & 2.32 & 0.16 & 2.04 & 2.13 & 0.15 & 3.79 & 0.00 & 0.47 & 0.00 & 1.68 & 0.13 & 0.02 & 78.51 & 0.00 & 92.15 \\
\hline 4 & 0.20 & 0.41 & 2.43 & 0.15 & 2.32 & 2.16 & 0.03 & 3.37 & 0.00 & 0.49 & 0.00 & 1.75 & 0.21 & 0.02 & 76.85 & 0.05 & 90.44 \\
\hline 5 & 0.24 & 0.35 & 2.93 & 0.19 & 2.10 & 1.95 & 0.00 & 5.63 & 0.00 & 0.46 & 0.03 & 1.73 & 0.26 & 0.00 & 75.64 & 0.06 & 91.57 \\
\hline 6 & 0.15 & 0.22 & 2.47 & 0.18 & 2.90 & 1.01 & 0.06 & 2.44 & 0.15 & 0.35 & 0.03 & 3.01 & 0.26 & 0.00 & 85.09 & 0.09 & 98.43 \\
\hline Average & 0.28 & 0.37 & 2.57 & 0.20 & 2.28 & 1.99 & 0.04 & 4.19 & 0.06 & 0.51 & 0.02 & 1.94 & 0.22 & 0.02 & 79.12 & 0.10 & 93.89 \\
\hline
\end{tabular}

XG-C-2: $\quad\left(\mathrm{K}_{0.37} \mathrm{Ca}_{0.28} \mathrm{Ag}_{0.13} \mathrm{Na}_{0.07} \mathrm{Mg}_{0.07} \mathrm{Zn}_{0.06} \mathrm{Cu}_{0.02}\right)_{1.00}$ $\left(\mathrm{Mn}_{7.01} \mathrm{Fe}_{0.40} \mathrm{Al}_{0.39} \mathrm{Si}_{0.03} \mathrm{Ti}_{0.01} \mathrm{Cr}_{0.01}\right)_{7.85} \mathrm{O}_{16}$ • $n \mathrm{H}_{2} \mathrm{O}$

The Ag contents in cryptomelane have been compared by LA-ICP-MS with ranciéite, chalcophanite and coronadite which also occur in this deposit (Table 2). The results show silver is remarkably concentrated in cryptomelane. Its concentrations are from ten to hundreds of times higher than those of other manganese oxides. The maximum amount of silver in cryptomelane as shown in Table 2 is $3.14 \mathrm{wt} \%$. From the EDS maps in Figure 3 the occurrence of $\mathrm{Ag}$ correlates positively to $\mathrm{Mn}$ and shows a uniform distribution in cryptomelane. Small amounts of other cations as $\mathrm{Pb}, \mathrm{Zn}, \mathrm{Ca}$ and $\mathrm{Fe}$ are also present in it. 
Table 2. Ag summary statistics of LA-ICP-MS analyses of different manganese oxide minerals from Xiangguang deposit

\begin{tabular}{cccc}
\hline $\begin{array}{c}\text { Mineral } \\
\text { (sample No.) }\end{array}$ & Datapoints & & $\mathrm{Ag}(\mu \mathrm{g} / \mathrm{g})$ \\
\hline Ranciéite & 14 & $\operatorname{Max}$ & 82.3 \\
& & {$[\mathrm{X}] \pm \sigma$} & $60.3 \pm 14.2$ \\
& & $\operatorname{Max}$ & 538.8 \\
Chalcophanite & 17 & $\operatorname{Min}$ & 83.9 \\
& & {$[\mathrm{X}] \pm \sigma$} & $250.0 \pm 150.7$ \\
& & $\operatorname{Max}$ & 319.6 \\
Coronodite & 19 & $\operatorname{Min}$ & 133.3 \\
& & {$[\mathrm{X}] \pm \sigma$} & $209.4 \pm 44.6$ \\
Cryptomelane & 12 & $\operatorname{Max}$ & 5442.5 \\
(XG-C-1) & & Min & 2195.9 \\
& & {$[\mathrm{X}] \pm \sigma$} & $3817.0 \pm 969.8$ \\
& & $\operatorname{Max}$ & 31469.4 \\
Cryptomelane & 14 & $\operatorname{Min}$ & 12050.4 \\
(XG-C-2) & & {$[\mathrm{X}] \pm \sigma$} & $18103.3 \pm 6089.3$ \\
\hline
\end{tabular}

\section{X-ray powder diffraction data}

Although the powder sample was selected as homogenous as possible using micro-drilling tools and presents a typical grey-black color of manganese oxide mineral, XRD patterns still often obtain lines of admixture components. X-ray diffraction analysis with a detection limit of about $5 \%$ indicates the presence of cryptomelane, quartz, and microcline in the sample $\mathrm{XG}-\mathrm{C}-1$ (Fig. 4). The diagnostic reflexes with d-values $(\AA)$ of $6.95,4.97$, 3.12 and 2.40 for cryptomelane in $\mathrm{XG}-\mathrm{C}-1$ are recognized in Figure 4 and other characteristic reflexes are also exhibited in Table 3. It is very difficult for routine XRD analysis to identify argentian cryptomelane in $\mathrm{XG}-\mathrm{C}-2$ due to its poor crystallinity and strong interference from silicate minerals. So a series of Raman experiments are executed to examine the manganese mineral phases using thin-sections of ore specimens.

\section{Raman spectroscopy}

No obvious Raman band at the $1000-3600 \mathrm{~cm}^{-1}$ spectral region is observed. So the Raman spectrums of argentian cryptomelane between $100 \mathrm{~cm}^{-1}$ and $800 \mathrm{~cm}^{-1}$ are recorded and compared with ranciéite, chalcophanite and coronadite in Figure 5. Argentian cryptomelane have several contributions at 577 (583), 628 (630), 509, 380 (386), 273 (279) and $183(184) \mathrm{cm}^{-1}$ in our samples. They give similar Raman responses with published data of cryptomelane shown in Table 4 . All these six Raman

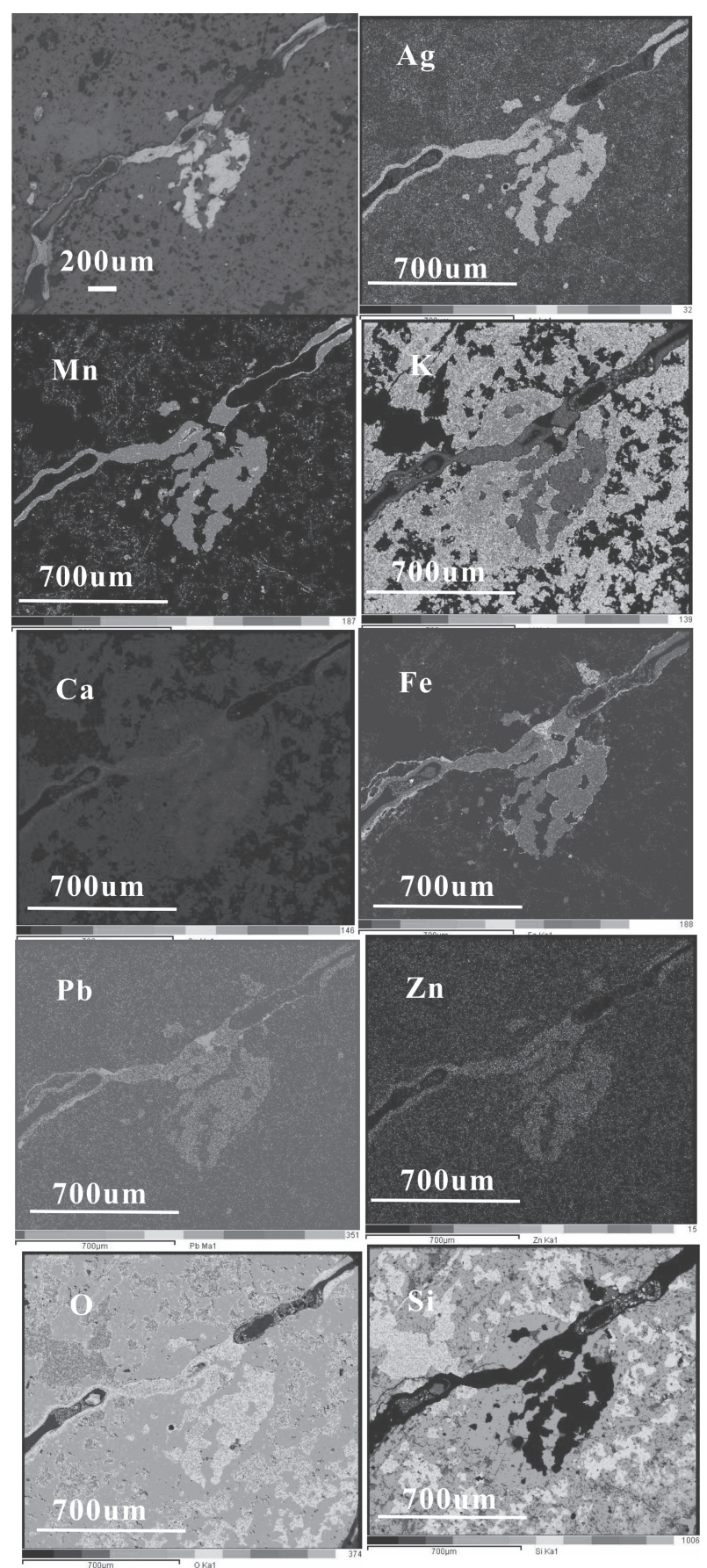

Figure 3. EDS maps of argentian cryptomelane in the sample $\mathrm{XG}^{-}$ C-2.

bands can be attributed to the $\mathrm{Mn}-\mathrm{O}$ lattice vibrations within the $\mathrm{MnO}_{6}$ octahedral double chains. $\alpha-\mathrm{MnO}_{2}$ type materials which cryptomelane belongs to have two diagnostic Raman active bands at high-frequency region, 574 $\mathrm{cm}^{-1}$ and $634 \mathrm{~cm}^{-1}$. They are due to the symmetric $\mathrm{Mn}-\mathrm{O}$ vibrations and are assigned to the $A_{g}$ spectroscopic species (Julien et al., 2003; Gao et al., 2008, 2009). The Raman band at $634\left(628,630\right.$ in this paper) $\mathrm{cm}^{-1}$ might 


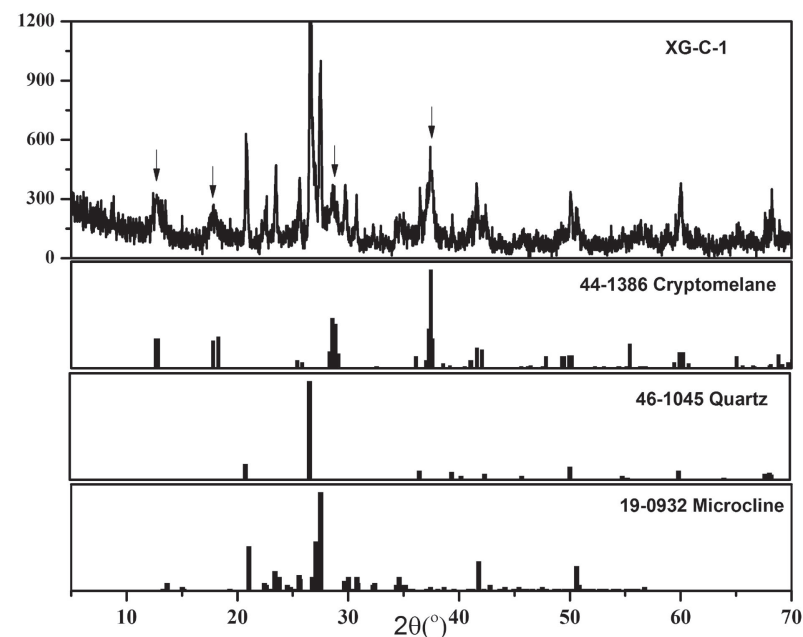

Figure 4. Powder $\mathrm{X}$-ray diffraction of argentian cryptomelane in the sample $\mathrm{XG}-\mathrm{C}-1$. Arrows denote the diagnostic diffraction peaks of cryptomelane.

Table 3. X-ray powder diffraction data for argentian cryptomelane from Xiangguang $\mathrm{Mn}-\mathrm{Ag}$ deposit

\begin{tabular}{lcccc}
\hline \multicolumn{2}{l}{ Cryptomelane(XG-C-1) } & \multicolumn{2}{c}{ PDF Card No. 44-1386 } \\
\hline $\mathrm{d}(\AA)$ & Relative intensity $\mathrm{d}(\AA)$ & $\mathrm{hkl}$ & $\begin{array}{l}\text { Relative } \\
\text { intensity }\end{array}$ \\
\hline 6.948 & 63 & 6.892 & $(101)$ & 10 \\
4.965 & 47 & 4.977 & $(200)$ & 14 \\
3.121 & 65 & 3.122 & $(301)$ & 39 \\
2.419 & 68 & 2.410 & $(21 \overline{1})$ & 40 \\
2.402 & 100 & 2.400 & $(211),(11 \overline{2})$ & 100 \\
2.392 & 79 & 2.391 & $(112)$ & 30 \\
2.169 & 68 & 2.168 & $(204),(310)$ & 23 \\
2.148 & 39 & 2.146 & $(013)$ & 21 \\
1.849 & 33 & 1.847 & $(41 \overline{1})$ & 16 \\
1.818 & 54 & 1.817 & $(114)$ & 17 \\
1.535 & 60 & 1.535 & $(21 \overline{5})$ & 25 \\
\hline
\end{tabular}

be related to the $\mathrm{Mn}-\mathrm{O}$ vibrations perpendicular to the direction of the $\mathrm{MnO}_{6}$ octahedral double chains. The Raman band at $574\left(577,583\right.$ in this paper) $\mathrm{cm}^{-1}$ may correspond to the displacement of the oxygen atoms relative to the manganese atoms along the octahedral chains (Julien et al., 2003; Gao et al., 2008). The presence of $\mathrm{Ag}$ and other cations changes the relative intensities of these two bands in our samples which can be used to characterize the tunnel structure of cryptomelane. The low-frequency Raman bands at $183(184) \mathrm{cm}^{-1}$ is assigned to an external vibration that derives from the translational motions of the $\mathrm{MnO}_{6}$ octahedra; the Raman band at $380(386) \mathrm{cm}^{-1}$ is ascribed to the $\mathrm{Mn}-\mathrm{O}$ bending vibrations (Gao et al., 2008). These low-frequency bands show weaker in $\mathrm{XG}-\mathrm{C}-2$ than those in $\mathrm{XG}-\mathrm{C}-1$ because
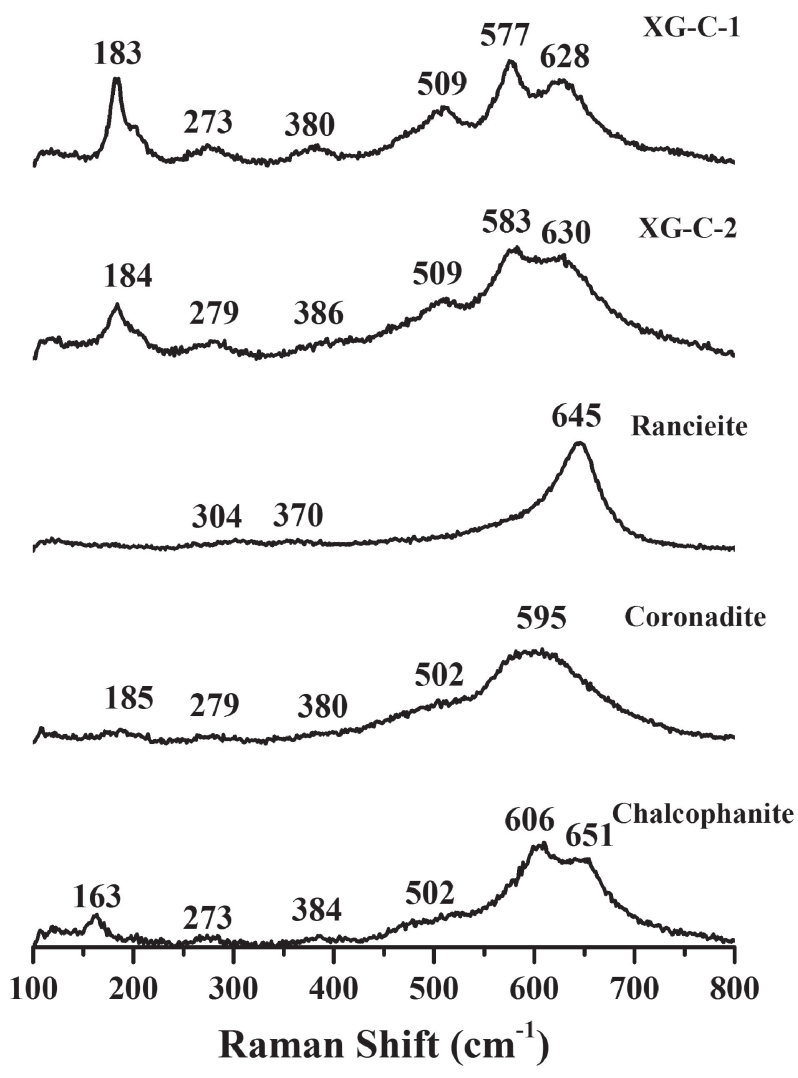

Figure 5. Raman spectra of argentian cryptomelane $(\mathrm{XG}-\mathrm{C}-1$ and $\mathrm{XG}-\mathrm{C}-2)$, ranciéite, chalcophanite and coronadite.

higher concentration of $\mathrm{Ag}$ and $\mathrm{Ca}$ might change the vibrational interactions of $\mathrm{O}-\mathrm{Mn}-\mathrm{O}-\mathrm{Mn}-\mathrm{O}$ chains.

Although both of coronadite and cryptomelane attribute to hollandite species, the doping cations of $\mathrm{K}$, $\mathrm{Ag}$ and $\mathrm{Pb}$ make the $\mathrm{Mn}-\mathrm{O}$ stretching vibration and translational motion of $\mathrm{MnO}_{6}$ octahedra different. The diagnostic high frequency bands combine into a broad peak centered at $595 \mathrm{~cm}^{-1}$ in coronadite and the low frequency band at $185 \mathrm{~cm}^{-1}$ becomes very weak. The cryptomelane also can be distinguished from ranciéite and chalcophanite having the layer structure by Raman spectrums. The important Raman change is observed on the symmetric stretching frequency $(\mathrm{Mn}-\mathrm{O})$ of $\mathrm{MnO}_{6}$ groups at 645 and $651 \mathrm{~cm}^{-1}$, which presents a shift of $15-20 \mathrm{~cm}^{-1}$ towards the high-wavenumber side for the ranciéite and chalcophanite respectively in comparison with cryptomelane.

The band located at $606 \mathrm{~cm}^{-1}$ might attribute to the $\mathrm{Mn}-\mathrm{O}$ stretching vibration in the basal plane of $\left[\mathrm{MnO}_{6}\right]$ sheet in chalcophanite, but the disappearance of this band in ranciéite might suggest a softening of the $\mathrm{Mn}-\mathrm{O}$ bond along the interlayer direction. Above all the local structure of manganese oxides with poor crystallinity are as a function of the nature of ions located in between the basal $\mathrm{MnO}_{6}$ sheets or tunnel. The effect of the cation incorpo- 
Table 4. Raman scattering data of manganese oxides in Xiangguang Mn-Ag deposit and references

\begin{tabular}{|c|c|c|c|c|c|c|c|c|c|c|c|}
\hline Minerals & \multicolumn{11}{|c|}{ Wavenumbers $\left(\mathrm{cm}^{-1}\right)$} \\
\hline \multirow{2}{*}{$\begin{array}{c}\text { Argentian } \\
\text { Cryptomelane }\end{array}$} & 183 & & 273 & & 380 & & & 509 & 577 & 628 & This paper \\
\hline & 184 & & 279 & & 386 & & & 509 & 583 & 630 & This paper \\
\hline \multirow{3}{*}{ Cryptomelane } & 183 & & 286 & 330 & 386 & & \multirow{3}{*}{$\begin{array}{l}470 \\
486 \\
467\end{array}$} & 512 & 574 & 634753 & \multirow{3}{*}{$\begin{array}{c}\text { (Gao et al., 2008) } \\
\text { (Hernández et al., 2010) } \\
\text { (Kim and Stair, 2004) }\end{array}$} \\
\hline & 188 & & 291 & & 395 & & & 519 & 588 & 643760 & \\
\hline & & \multicolumn{5}{|c|}{321} & & & \multicolumn{2}{|c|}{571} & \\
\hline \multirow{4}{*}{ Coronadite } & 185 & & 279 & & 380 & & \multirow{4}{*}{484} & 502 & 595 & & \multirow{4}{*}{$\begin{array}{l}\text { This paper } \\
\text { RRUFF database No. R060258 } \\
\text { RRUFF database No. R070320 } \\
\text { RRUFF database No. R090056 }\end{array}$} \\
\hline & & & 263 & & 385 & & & & 563 & & \\
\hline & & & 268 & & 386 & & & & 583 & & \\
\hline & 155 & & 280 & & 378 & 449 & & 496 & 572 & & \\
\hline \multirow{6}{*}{ Chalcophanite } & 163 & & 273 & \multirow{3}{*}{330} & 384 & & & 502 & 606 & 651 & \multirow{6}{*}{$\begin{array}{c}\text { This paper } \\
\text { (Kim and Stair, 2004) } \\
\text { (Pitarch et al., 2014) } \\
\text { RRUFF database No. R050451 } \\
\text { RRUFF database No. R050605 } \\
\text { RRUFF database No. R060271 }\end{array}$} \\
\hline & & & & & 392 & 450 & & 500 & 560 & 673 & \\
\hline & & & & & & & & & 570 & 670 & \\
\hline & & 242 & & \multirow[t]{3}{*}{321} & 376 & 450 & \multirow{3}{*}{$\begin{array}{l}482 \\
484 \\
485\end{array}$} & $510 \quad 542$ & 644 & 689 & \\
\hline & 175 & 219 & & & 385 & & & 512 & 570 & 669 & \\
\hline & 177 & 219 & & & 388 & & & 512 & 569 & 670 & \\
\hline Ranciéite & & & 301 & & 370 & & & & & 645 & This paper \\
\hline
\end{tabular}

ration into the interlayer or tunnel space results in disordered $\mathrm{Mn}-\mathrm{O}$ chemical bonds and change in the covalency of $\mathrm{MnO}_{6}$ octahedra and a partial reduction of the $\mathrm{Mn}^{4+}$ ions which results in a modification of the vibrational mode frequencies that is inherent to the presence of low valence of Mn ions (Julien et al., 2003). However, an unequivocal assignment of some bands and the other weak bands is difficult in this stage, and these Raman modes reported here will be pursued in our succeeding studies.

\section{Transmission electron microscopy}

TEM study reveals well crystallized cryptomelane with plate-like sheets in $\mathrm{XG}-\mathrm{C}-1$, but tiny to amorphous grains in XG-C-2 (Figs. 6a and 7a). The interplanar distances of 6.92, 3.11 and $4.97 \AA$ corresponds with (101), (301), (200) reflection of the cryptomelane phase respectively in XG-C-1 (Figs. 6b and 6c). Another argentian cryptomelane in $\mathrm{XG}-\mathrm{C}-2$ have characteristic interplanar distances of 6.9-7.0, 4.9 and 3.1-3.2 $\AA$ (Figs. 7c and 7d). The developed structural defects as lattice dislocations, distortions and stria combinations make the crystal fringes diverse (Figs. 6d and 7b).

\section{DISCUSSION}

Nanometric native silver has been reported to be adsorbed on todorokite at the San Miguel Tenango Mn-Ag mine (Gómez-Caballero et al., 2010), but it was not observed in argentian cryptomelane during our TEM and Raman

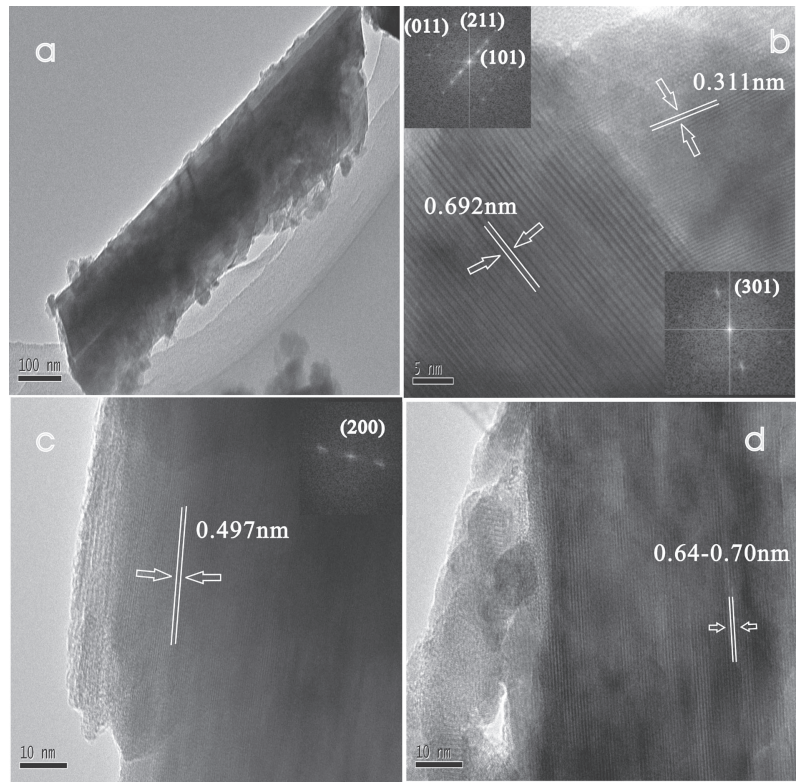

Figure 6. High resolution TEM image of argentian cryptomelane in the sample $\mathrm{XG}-\mathrm{C}-1$.

experiments. SEM-EDS maps also show the uniform distribution of silver in cryptomelane instead of local enrichment. So it is more probably for Ag cations to be accommodated into the atomic architectures rather than nanometric silver minerals to be adsorbed on the surface of cryptomelane.

The compositional and structural properties of cryptomelane have been studied in considerable detail by 


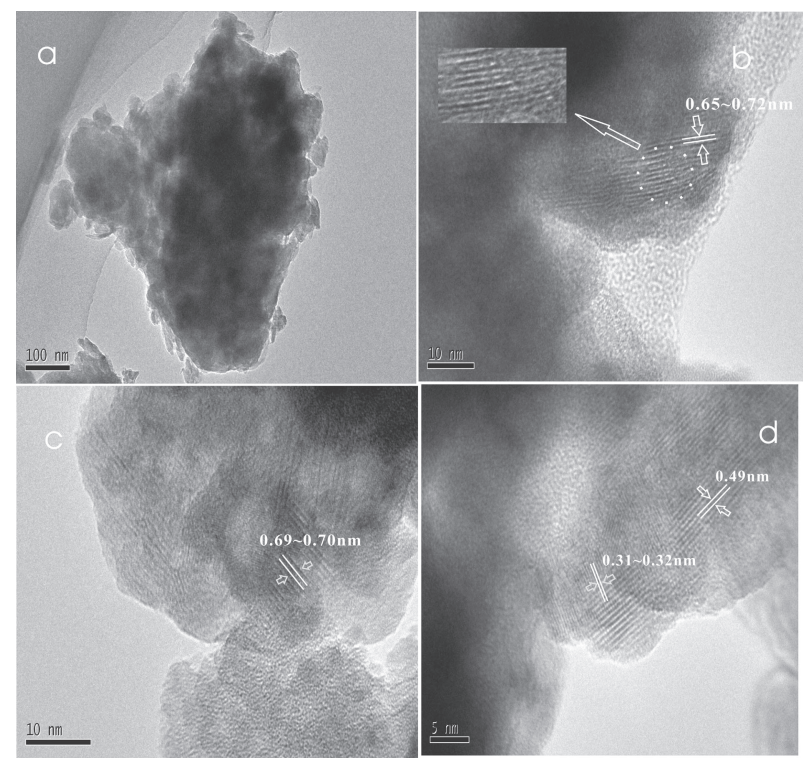

Figure 7. High resolution TEM image of argentian cryptomelane in the sample $\mathrm{XG}-\mathrm{C}-2$.

many researchers (Bystörm and Bystörm, 1950; Post et al., 1982). It is a typical $2 \times 2$ tunnel structure manganese oxide, which is composed of edge-sharing double $\left[\mathrm{MnO}_{6}\right]$ octahedral chains (Post et al., 1982; Lu et al., 2003). The substitution of $\mathrm{Mn}^{4+}$ by $\mathrm{Mn}^{3+}$ and/or $\mathrm{Mn}^{2+}$ in the framework can be balanced by the insertion of large monovalent cation- $\mathrm{K}$ within the tunnel (Pasero, 2005). The presence of potassium is necessary for the formation of cryptomelane to prevent the tunnel structure from collapsing. The two $\mathrm{K}$ positions per unit cell are only half filled, because the short $\mathrm{K}-\mathrm{K}$ distance of 0.28 $\mathrm{nm}$ will make the structure unstable due to repulsive forces between the cations if all of the $\mathrm{K}$ sites are filled (Bystörm and Bystörm, 1950). The upper limit for potassium in cryptomelane is about $7 \mathrm{wt} \%$, while the lower limit lies between $0.25 \mathrm{wt} \%$ and $2.2 \mathrm{wt} \% \mathrm{~K}$ (Burser et al., 1954; McKenzie, 1971).

Cryptomelane have several $2 \times 2$ tunnel structure analogues in nature. Barium, lead and sodium cations which have large radii similar to that of potassium can proxy for potassium as in the high-barium mineral hollandite, the plumbous mineral coronadite and the sodium-rich mineral manjiroite (Bystörm and Bystörm, 1950; Nambu and Tanida, 1967; Post and Bish, 1989). The states of oxidation of manganese partly determine what kind and how much mono- or divalent cations can enter the tunnels at the time the manganese minerals form (Gruner, 1943; Hildebrand and Mosier, 1974). Furthermore, silver, cesium, copper, nickel, lithium, cobalt, chromium-modified cryptomelane are reported to be synthesized successfully (Santos et al., 2009; Hernández et
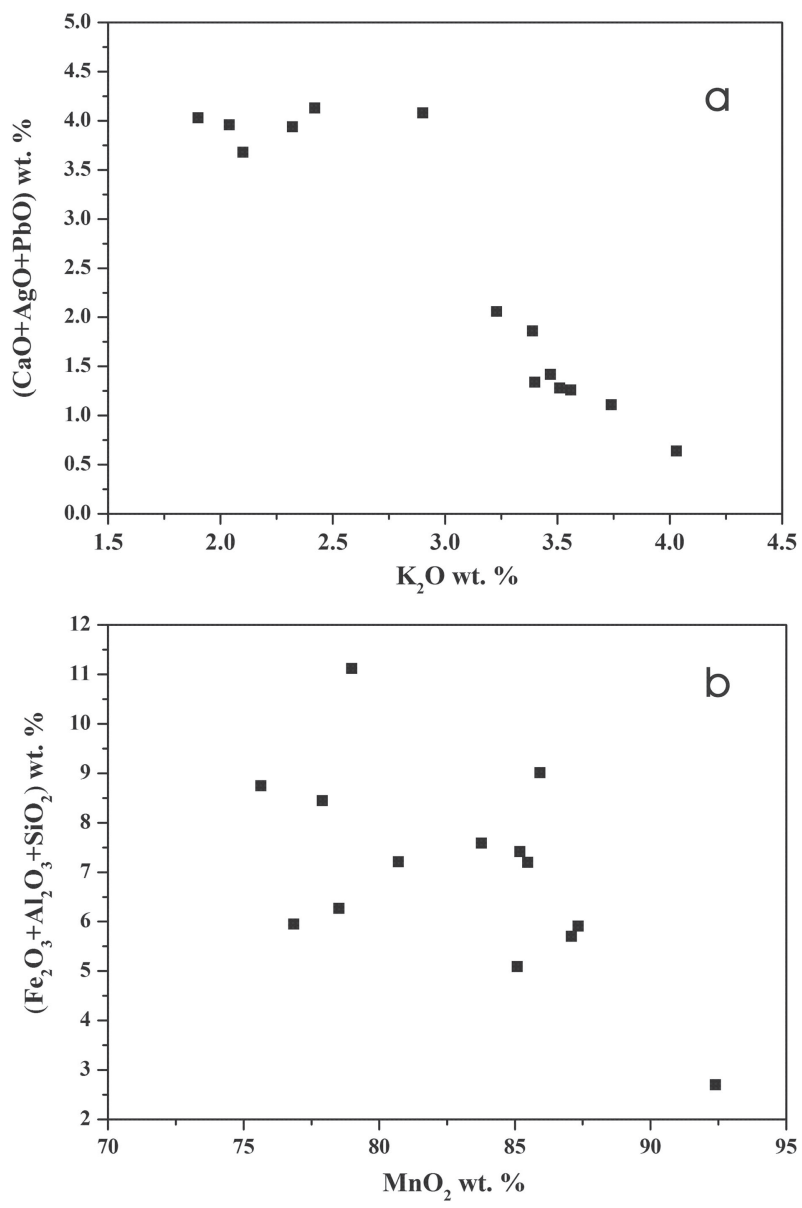

Figure 8. Correlation plots of (a) $(\mathrm{CaO}+\mathrm{AgO}+\mathrm{PbO})$ versus $\mathrm{K}_{2} \mathrm{O}$. (b) $\left(\mathrm{Fe}_{2} \mathrm{O}_{3}+\mathrm{Al}_{2} \mathrm{O}_{3}+\mathrm{SiO}_{2}\right)$ versus $\mathrm{MnO}_{2}$ in argentian cryptomelane from Xiangguang deposit.

al., 2012; Özacar et al., 2013; Sun et al., 2014). These cations partially occupy locations within the tunnels to stabilize charge. In most cases minor distortions of the framework and/or ordered distributions of cations cause some deviation of the symmetry of these modified cryptomelane (Pasero, 2005).

The structure of cryptomelane allows considerable flexibility in chemical composition as a result not only of tunnel cation exchange, but also of octahedral framework replacements (Pasero, 2005). In nature the composition of cryptomelane also depends upon what elements are available in the solutions at the time of formation (Hildebrand and Mosier, 1974). For this reason, cryptomelane has a wide compositional variability of $\mathrm{K}, \mathrm{Ag}, \mathrm{Ca}$, $\mathrm{Pb}, \mathrm{Al}, \mathrm{Fe}$ and Si contents in Xiangguang Mn-Ag deposit (Table 1). Regardless of those elements less than $1 \mathrm{wt} \%$, elemental correlation plots of $(\mathrm{AgO}+\mathrm{PbO}+\mathrm{CaO})$ concentrations vs $\mathrm{K}_{2} \mathrm{O}$ concentrations and $\left(\mathrm{Fe}_{2} \mathrm{O}_{3}+\mathrm{Al}_{2} \mathrm{O}_{3}+\right.$ $\mathrm{SiO}_{2}$ ) concentrations versus $\mathrm{MnO}_{2}$ concentrations are shown in Figure 8. $(\mathrm{AgO}+\mathrm{PbO}+\mathrm{CaO})$ contents show 
well defined negative correlation trends with $\mathrm{K}_{2} \mathrm{O}$ (Fig. 8a). The result illustrates the substitution relationship of mono- and divalent cations to potassium, which also means silver, calcium and lead probably occupy the tunnel sites in cryptomelane instead of potassium. The ionic radius and valence states are regarded as the most important factors that determine which cations can be stably doped in the tunnel of cryptomelane in natural conditions (Turner and Buseck, 1979; Post, 1999; Pasero, 2005). The radius of $\mathrm{Ag}^{+}(1.26 \AA)$ is adjacent to that of $\mathrm{K}^{+}(1.33 \AA)$ and $\mathrm{Pb}^{2+}(1.20 \AA)$, but both silver and potassium are monovalent while lead is divalent. So it is more suitable for silver to enter the structure of cryptomelane involving substitution of potassium than coronadite involving substitution of lead. That explains why higher silver contents in cryptomelane than coronadite shown in Table 2. In addition, the elements of $\left(\mathrm{Fe}_{2} \mathrm{O}_{3}+\mathrm{Al}_{2} \mathrm{O}_{3}+\mathrm{SiO}_{2}\right)$ appear to negatively correlate with $\mathrm{MnO}_{2}$, but the trends are more scattered (Fig. 8b). It is possibly due to EMPA calculation contributing $\mathrm{Mn}^{2+}, \mathrm{Mn}^{3+}$ to $\mathrm{Mn}^{4+}$ which results in higher $\mathrm{MnO}_{2}$ content than the actual value. Trivalent aluminum, iron and tetravalent silicon could replace manganese in the $\left[\mathrm{MnO}_{6}\right]$ octahedron shared by corners and/or edges, in comparison with, in general, $\mathrm{SiO}_{4^{-}}$and $\mathrm{AlO}_{6^{-}}$frameworks of the aluminosilicates.

Silver (1.2-3 wt\%) and calcium (2-3 w\%) contents are not sufficient to change the ratio of $\mathrm{Mn}$ vs other cations $(\mathrm{K}+\mathrm{Ag}+\mathrm{Ca} \ldots) \approx 8: 1$ in the cryptomelane compositions of XG-C-2, but some lattice distortions are caused by these substitutions. The Mn-O lattice vibrations within the $\mathrm{MnO}_{6}$ octrahedral double chains are weakened in Raman spectroscopy (Fig. 5). The substitutions of calcium together with silver might give a great effort to some lattice distortions including the configurations of variously sized tunnel structures and considerable positional disorders on the tunnel sites due to different valence state and smaller radius of $\mathrm{Ca}^{2+}(0.99 \AA)$ in comparison of $\mathrm{K}^{+}(1.33 \AA)$. Furthermore, except the predominant tunnel positions, silver ions may present on the surface of the cryptomelane as well (Ravikumar et al., 1998). However, our observation is limited to the instrument conditions, so more advanced sample preparation method and aberration-corrected $\mathrm{Z}$ contrast imaging of this mineral to discover its detailed crystal structure will be done further.

\section{ACKNOWLEDGMENTS}

This work is supported by the National Science Foundation of China (Grant No. 41302030) and the Geological Survey Project of China (Grant No. 12120113015100) to C. Fan.

\section{REFERENCES}

Anderson, B.J., Jenne, E.A. and Chao, T.T. (1973) The sorption of silver by poorly crystallized manganese oxides. Geochimica et Cosmochimica Acta, 37, 611-622.

Burser, W., Graf, P. and Feiknecht, W. (1954) Beitrag zur kenntnis der mangan(ii)-manganite und delta- $\mathrm{MnO}_{2}$. Helvetica Chimica Acta, 37, 2322-2323.

Bystörm, A. and Bystörm, A.M. (1950) The Crystal Structure of Hollandite, the Related Manganese Oxide Minerals, and $\alpha^{-}$ $\mathrm{MnO}_{2}$. Acta Crystallogr, 3, 146-153.

Gac, W. (2006) FT-IR/PAS studies of the silver modified manganese oxides. Journal de Physique Archives, 137, 283-286.

Gao, T., Glerup, M., Krumeich, F., Nesper, R., Fjellvag, H. and Norby, P. (2008) Microstructures and spectroscopic properties of cryptomelane-type manganese dioxide nanofibers. The Journal of Physical Chemistry C, 112, 13134-13140.

Gao, T., Fjellvag, H. and Norby, P. (2009) A comparison study on Raman scattering properties of $\alpha-$ and $\beta-\mathrm{MnO}_{2}$. Analytica Chimica Acta, 648, 235-239.

Gómez-Caballero, J.A., Villaseñor-Cabral, M.G., Santiago-Jacinto, P. and Ponce-Abad, F. (2010) Hypogene Ba-rich todorokite and associated nanometric native silver in the San Miguel Tenango mining area, Zacatlán, Puebla, Mexico. The Canadian Mineralogist, 48, 1237-1253.

Gruner, J.W. (1943) The chemical relationship of cryptomelane (psilomelane), hollandite, and coronadite. American Mineralogist, 28, 497-506.

Hernández, H.Y., Centeno, M.A., Ivanova, S., Eloy, P., Gaigneaus, E.M. and Odriozola, J.A. (2012) Cu-modified cryptomelane oxide as active catalyst for $\mathrm{CO}$ oxidation reactions. Applied Catalysis B: Environmental, 123-124, 27-35.

Hildebrand, F.A. and Mosier, E.L. (1974) Argentian cryptomelane and bromargyrite in volcanic rocks near Silver Cliff, Colorado. U.S. Geological Survey Bulletin 1382-C.

Julien, C., Massot, M., Baddour-Hadjean, R., Franger, S., Bach, S. and Pereira-Ramos, J.P. (2003) Raman spectra of birnessite manganese dioxides. Solid State Ionics, 159, 345-356.

Kim, H.S. and Stair, P.C. (2004) Bacterially produced manganese oxide and todorokite: UV Raman spectroscopic comparison. The Journal of Physical Chemistry B, 108, 17019-17026.

Li, S.Y., Li, Y. and Lai, L.R. (1996) Techonological mineralogy of silver in argentiferous deposits of China. Geological Press, Beijing (in Chinese).

Liu, C.W., Gu, Z.F., Wei, M.H., Chen, S.Q., Yang, Y. and Li, Y.H. (2012) Metallogenic characteristics and formation mechanism of the Xianggguang $\mathrm{Mn}-\mathrm{Ag}$ ore deposit, Hebei. Mineral Exploration, 3, 164-170 (in Chinese with English abstract).

Lu, A., Gao, X., Qin, S. and Wang, C. (2003) Cryptomelane $\left(\mathrm{K}_{\mathrm{x}}\right.$ $\mathrm{Mn}_{8-\mathrm{x}} \mathrm{O}_{16}$ ): Natural active octahedral molecular sieve (OMS2). Chinese Science Bulletin, 48, 920-923.

McKenzie, R.M. (1971) The synthesis of birnessite, cryptomelane, and some other oxides and hydroxides of manganese. Mineralogical Magazine, 38, 493-502.

Nambu, M. and Tanida, K. (1967) Manjiroite, a new manganese dioxide mineral, from Kohare mine, Iwate Prefecture, Japan. Journal of the Japanese Association for Mineralogy and Petrology, 58, 39-54.

Özacar, M., Poyraz, A.S., Genuino, H.C., Kuo, C.H., Meng, Y.T. and Suib, S.L. (2013) Influence of silver on the catalytic properties of the cryptomelane and Ag-hollandite types manga- 
nese oxides OMS-2 in the low-temperature CO oxidation. Applied Catalysis A: General, 462-463, 64-74.

Pasero, M. (2005) A short outline of the tunnel oxides. Reviews in Mineralogy and Geochemistry, 57, 291-305.

Pitarch, A., Ruiz, J.F., Fdez-Ortiz de Vallejuelo, S., Hernanz, A., Maguregui, M. and Madariaga, J.M. (2014) In situ characterization by Raman and X-ray fluorescence spectroscopy of post-Paleolithic blackish pictographs exposed to the open air in Los Chaparros shelter (Albalate del Arzobispo, Teruel, Spain). Analytical Methods, 6, 6641-6650.

Post, J.E., Von Dreele, R.B. and Buseck, P.R. (1982) Symmetry and cation displacements in hollandites: structure refinements of hollandite, cryptomelane and priderite. Acta Crystallogr, B38, 1056-1065.

Post, J.E. and Bish, D.L. (1989) Rietveld refinement of the coronadite structure. American Mineralogist, 74, 913-917.

Post, J.E. (1999) Manganese oxide minerals: crystal structures and economic and environmental significance. Proceedings of the National Academy of Sciences of the United States of America, 96, 3447-3454.

Radtke, A.S., Taylor, C.M. and Hewett, D.F. (1967) Aurorite, argentian todorokite, and hydrous silver-bearing lead manganese oxide. Economic Geology, 62, 186-206.

Ravikumar, R.R., Fuerstenau, D.W. and Waychunas, G.A. (1998) Charaterization of silver binding in cryptomelane by X-ray absorption spectroscopy. MRS Proceedings, 524, 353-358.

Santos, V.P., Pereira, M.F.R., Órfäo, J.J.M. and Figueiredo, J.L. (2009) Catalytic oxidation of ethyl acetate over a cesium modified cryptomelane catalyst. Applied Catalysis B: Environmental, 88, 550-556.

Sun, H., Qiu, G., Feng, X., Yin, H. and Liu, F. (2014) Effects of Co and $\mathrm{Ni}$ co-doping on the physicochemical properties of cryptomelane and its enhanced performance on photocatalytic degradation of phenol. Materials Chemistry and Physics, $148,783-789$.

Takeuchi, K.J., Yau, S.Z., Menard, M.C., Marschilok, A.C. and Takeuchi, E.S. (2012) Synthetic control of composition and crystallite size of silver hollandite, $\mathrm{Ag}_{\mathrm{x}} \mathrm{Mn}_{8} \mathrm{O}_{16}$ : impact on electrochemistry. Applied Materials and Interfaces, 4, 55475554.

Takeuchi, K.J., Yau, S.Z., Subramanian, A., Marschilok, A.C. and Takeuchi, E.S. (2013) The electrochemistry of silver hollandite nanorods, $\mathrm{Ag}_{\mathrm{x}} \mathrm{Mn}_{8} \mathrm{O}_{16}$ : enhancement of electrochemical battery performance via dimensional and compositional control. Journal of the Electrochemical Society, 160, A3090A3094.

Tian, Q.H., Jiao, C.Y. and Guo, X.Y. (2012) Extraction of valuable metals from manganese-silver ore. Hydrometallurgy, 119$120,8-15$.

Turner, S. and Buseck, P.R. (1979) Manganese oxide tunnel structures and their intergrowths. Science, 203, 456-458.

Manuscript received January 19, 2015

Manuscript accepted August 6, 2015

Manuscript handled by Norimasa Shimobayashi 